\title{
Soil salinity variations and cotton growth under long-term mulched drip irrigation in saline-alkali land of arid oasis
}

\author{
Wenhao $\mathrm{Li}^{1,2,3} \cdot$ Zhenhua Wang $^{1,2} \odot \cdot$ Jinzhu Zhang ${ }^{1,2} \cdot$ Rui Zong $^{1,2}$
}

Received: 14 June 2021 / Accepted: 22 September 2021 / Published online: 21 October 2021

(c) The Author(s) 2021

\begin{abstract}
The sustainable development and utilization of saline-alkali land are closely related to holding fast the minimum cultivated land area of China. The change of soil salt in cotton field under long-term mulched drip irrigation (MDI) is connected with the development of the national cotton industry. From 2015 to 2019, five cotton fields with different applying years of MDI, which were reclaimed in 2004, 2008, 2010, 2012 and 2015 respectively and were saline-alkali wasteland before, were monitored continuously in the Manas River irrigation area of Xinjiang. By means of continuous location monitoring and spatial-temporal variability (For example, the monitoring data of cotton fields under MDI in 2004, 2008, 2010, 2012 and 2015, and in the year of 2015 were counted as $12,8,6,4$ and 1 years, respectively), the spatial-temporal variations of soil salt and ions in cotton field with 1-16a MDI technology were presented. The cotton growth characteristics and its main influencing factors were also analyzed in the study. The results showed that saline-alkali cotton field experienced changed from intensive saline soil to moderate saline soil and finally to non-saline soil under long-term MDI. The change of soil salt and the response of cotton growth to soil salt were divided into three typical stages. Firstly, soil desalinated rapidly in 1-4a MDI cotton field, which the annual average desalination rate was $24.93 \%$ in $0-100 \mathrm{~cm}$ soil layer (root zone). Additionally, the survival rate of cotton rocketed from $1.48 \%$ to $42.04 \%$, and yield increased sharply from $72.43 \mathrm{~kg} \mathrm{ha}^{-1}$ to $3075.90 \mathrm{~kg} \mathrm{ha}^{-1}$. Soil desalination was lower in 5-11a MDI cotton field, which the annual average desalination rate was $10.92 \%$ at the root zone. The annual survival rate and yield of cotton increased by $6.26 \%$ and $5.18 \%$, respectively. After 12a MDI, the soil salt in cotton field tended to be generally constant, which the average salt content in root zone was less than $2.49 \mathrm{~g} \mathrm{~kg}^{-1}$. The survival rate of cotton was stable above $90.39 \%$, and the yield per unit area exceeded $5401.32 \mathrm{~kg} \mathrm{ha}^{-1}$. Ions, sodium absorption ratio and $\mathrm{Cl}^{-}$and $\mathrm{SO}_{4}{ }^{2-}$ equivalent ratio (CSER) in cotton soil also decreased with the extension of MDI. Salt composition changed year by year, but the type of intensive saline soil had always been chloride-sulphate solonchak $(0.2<\mathrm{CSER}<1)$. In practice, with a higher irrigation quota and ideal irrigation water quality, the soil salt environment of saline-alkali soil MDI cotton field had developed in favor of cotton growth in an oasis irrigation area. However, this management practice caused between 124.21-143.61 mm of water resources waste. Therefore, we should further enhanced the consciousness of watersaving and implemented quota management in practice.
\end{abstract}

\section{Introduction}

The saline-alkali soil improvement has always been a hot and difficult issue concerned by related experts worldwide

Zhenhua Wang

wzh2002027@163.com

1 College of Water and Architectural Engineering, Shihezi University, Shihezi 832000, Xinjiang, China

2 Key Laboratory of Modern Water-Saving Irrigation of Xinjiang Production and Construction Group, Shihezi University, Shihezi 832000, Xinjiang, China

3 College of Water Resources and Civil Engineering, China Agricultural University, Beijing 100083, China (Sahin et al. 2011; Zheng et al. 2017). In Xinjiang arid region, the saline-alkali land is mainly distributed in oasis areas, accounting for approximately $1 / 3$ of the total salinealkali land area in China (Casas et al. 2019; Fang et al. 2019). There is a great practical significance to developing and utilizing the saline-alkali land reasonably, promoting regional development and sticking to the minimum cultivated land area of China. Mulched drip irrigation (MDI) technology can regulate the distribution of soil salt to 
improve the environment for root growth ( $\mathrm{Li}$ et al. 2019; Muhammad et al. 2021). MDI has greatly promoted the development of the regional cotton industry since being introduced by Xinjiang Production and Construction Corps in 1996 (Wang et al. 2019). Despite the limitations of the soil salt level in cotton plantations, Xinjiang's cotton planting area accounted for $78.00 \%$ of the country's total area in 2020 , with a total yield proportion of $87.00 \%$, according to the cotton production report issued by the National Bureau of Statistics. However, whether this water-saving irrigation technology has led to further salt accumulation or secondary salinization in the cotton field has been a concern by many scholars.

A few researchers thought that with the extended application of MDI, the salt content within $0-40 \mathrm{~cm}$ or $0-60 \mathrm{~cm}$ layer in cotton fields continuously decreased, and even desalination occurred in the whole unsaturated zone in some shallow groundwater areas (Guan et al. 2019; Li et al. 2012; Tan et al. 2008). Other scholars pointed out that high-frequency and low-amount drip irrigation might desalinate the surface soil of bare land during the cotton growth period, and salt was concentrated in $0-40 \mathrm{~cm}$ soil layer in the middle of the two plastic films without mulching. However, the increase in soil salt was observed along the $0-60 \mathrm{~cm}$ soil profile after cotton harvest, causing a net accumulation of salt (Rohit Katuri et al. 2019; Wang et al. 2019; Yang et al. 2011). Ning (2015) indicated that MDI in different hydrological years alternatively resulted in soil salt desalination and accumulation. Due to the different experimental conditions, soil salinity variations in the cotton field with long-term MDI were different. And the majority of the literature focused on the change of soil salt and less attention on the variations of the salt components. On the other hand, in production practice, the response characteristics of cotton growth to soil salinity variations in long-term MDI cotton fields are related to the development of the cotton industry.

In this study, five cotton fields with MDI of were monitored from 2015 to 2019. The continuous location monitoring combined with spatial-temporal variability were used to study: (1) salt, ions distribution and variation characteristics in long-term MDI cotton fields; (2) changes in sodium absorption ratio and $\mathrm{Cl}^{-}$and $\mathrm{SO}_{4}{ }^{2-}$ equivalent ratio (CSER) during this process; and (3) the survival rate and yield of cotton with the variations of salinity. The reliability of the results was guaranteed by the method of continuous location monitoring combined with spatial-temporal variability. Field data for 16 consecutive years made up for the short comings of previous studies and reflected the evolution process of salinity in MDI cotton field over a long time scale. The results will provide a reference for the sustainable application of MDI technology and technical support for the development of the cotton industry.

\section{Materials and methods}

\section{Experimental design}

The study area is located in a typical inland arid oasis irrigation area, Paotai town, Shihezi city, in the Xiayedi irrigation area of the Manas River Basin in Xinjiang (Fig. 1a, b). Region experiences a typical arid continental climate, with an average annual rain-fall of $215 \mathrm{~mm}$. Accumulated rainfall from 2015 to 2019 was $151.4,168.3,219.6,204.6$ and $225.7 \mathrm{~mm}$, respectively. In 1996, the Xinjiang Production and Construction Corps introduced and tested MDI technology on the saline-alkali land of Paotai town. In April 2015, five cotton fields, which reclamation time was 2004, 2008, 2010, 2012 and 2015, respectively, was selected in Paotai town with annual use of MDI technology. Before reclamation, all fields were a saline-alkali wasteland and belonged to the same tributary canal of water conveyance irrigation (Fig. 1c). The MDI technology was adopted to plant cotton successively. The cotton varieties, the irrigation and fertilization systems were basically the same for these lands. The same planting pattern was applied (Fig. 2). To be close to the actual production, the experiment took the farmers' high-yield experience as the basis for determining the irrigation quota. The irrigation periods mainly depended on the water consumption law of cotton, at the same time, the rotation of irrigation in the irrigation area should also be considered. The irrigation schedule of the study location during 2015-2019 is shown in Table 1. Irrigation water was imported from the Manas River, and the average salinity during 2015-2019 were $0.79,0.75,0.68,0.83$ and $0.69 \mathrm{~g} \mathrm{~L}^{-1}$, respectively, which fitted the water quality requirements for irrigation water (maximum of $2 \mathrm{~g} \mathrm{~L}^{-1}$ ) (Lothrop et al. 2018). The cotton fields were managed with the integration of water and fertilizer technology, and the average annual $\mathrm{N}$ and $\mathrm{K}$ application rates were $374 \mathrm{~kg} \mathrm{ha}^{-1}$ and $103 \mathrm{~kg} \mathrm{ha}^{-1}$, respectively.

Spot-sampling at a fixed time was performed from 2015 to 2019 . To accurately gauge the changes in soil salt during the growth period of cotton under MDI, samples were collected in the middle of April and October every year. Irrigation was halted 2 days before sampling, and sampling times were required that there was no rain during the previous 4-5 days. The years of MDI in the cotton field calculated by the spatial-temporal variability method are shown in Fig. 1d. In April 2015, soil particle size distributions from each layer were tested with a hydrometer, and soil texture was classified according to the results of Morais et al. (2019). The soil bulk density was measured by the cutting-ring method. The soil basic physical properties in $0-100 \mathrm{~cm}$ soil layer are presented in Table 2 . Soil 
Fig. 1 Study area location and spatial-temporal variability method display. a The study area is located in the Manas River Basin in northern Xinjiang. b Paotai town in Shihezi city, typical arid oasis irrigation area. $\mathbf{c}$ The cotton fields that were reclaimed with MDI technology in 2004 (A), 2008 (B), 2010 (C), 2012 (D) and 2015

(E) were selected, respectively. d Cotton fields were sampled from 2015 to 2019, and the spatial-temporal variability method was used to form data for 1-16 years of MDI

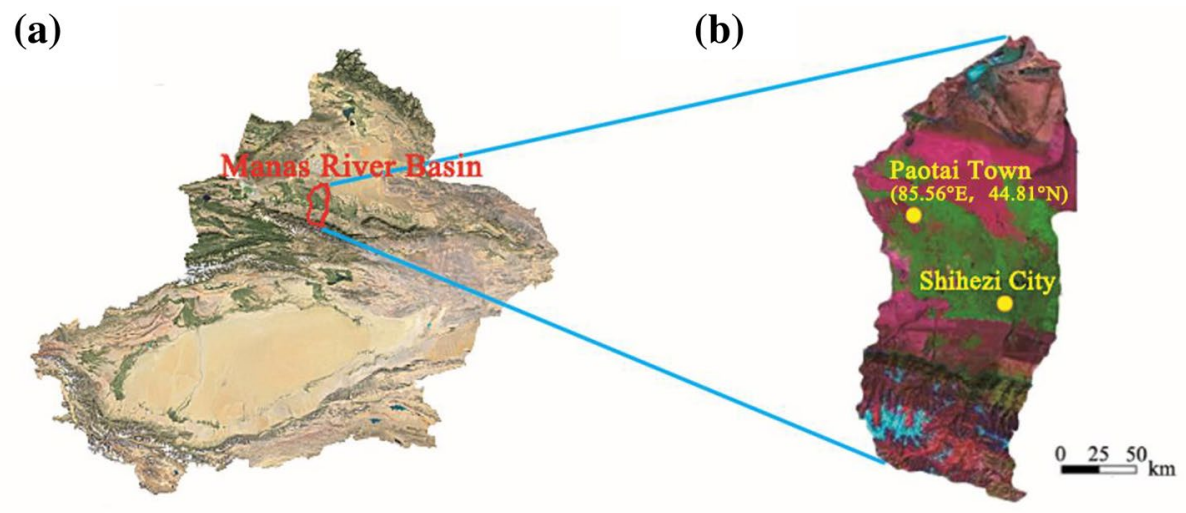

(c)

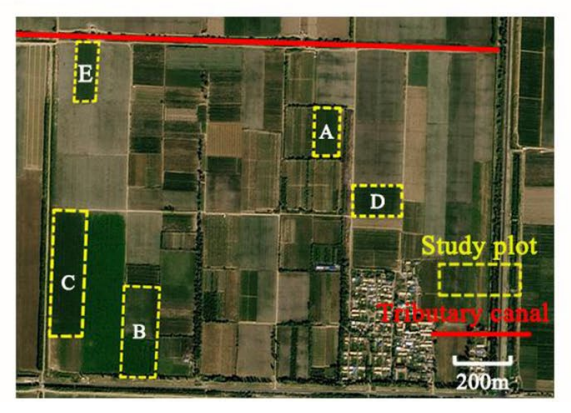

(d)

\begin{tabular}{c|ccccc}
\multicolumn{5}{c}{ Years of MDI } \\
$\begin{array}{c}\text { Sampling } \\
\text { Start year } \\
\text { year (Plot) }\end{array}$ & 2015 & 2016 & 2017 & 2018 & 2019 \\
\hline $2004(\mathrm{~A})$ & 12 & 13 & 14 & 15 & 16 \\
2008 ( B ) & 8 & 9 & 10 & 11 & 12 \\
2010 ( C ) & 6 & 7 & 8 & 9 & 10 \\
$2012(\mathrm{D})$ & 4 & 5 & 6 & 7 & 8 \\
2015 ( E ) & 1 & 2 & 3 & 4 & 5 \\
\hline
\end{tabular}

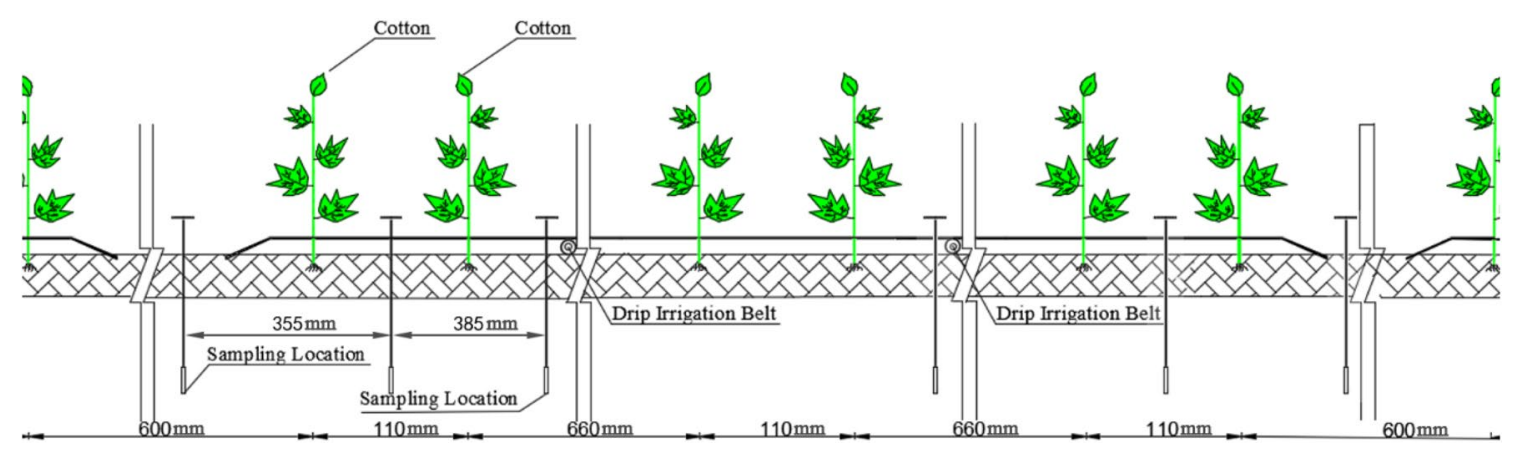

Fig. 2 The planting pattern used one plastic sheet and two lines of drip irrigation tape for every six rows of cotton. These rows were clustered in pairs that were $110 \mathrm{~mm}$ apart, with $660 \mathrm{~mm}$ between non-paired rows and $600 \mathrm{~mm}$ between plastic sheets. And three sam- pling points were chosen within each sampling zone: (1) below the drip irrigation tape, (2) in the middle of the narrow row, (3) the gap between sheets of plastic film texture was relatively uniform in the cultivated layer. The underground water level and salinity in April and October for the period 2014-2019 were monitored (Fig. 3).

\section{Experimental methods}

\section{Sampling and sample processing methods}

The three sampling zones in the cotton field were located at $1 / 4,1 / 2$, and $3 / 4$ of the distance along the diagonal line running from the northeast corner of the field to the southwest corner. All sampling zones were marked after the first sampling to ensure consistency. Three sampling points were chosen within each sampling zone: one was located under the drip irrigation tape, and one was in the middle of the narrow rows, and the other was between the mulching films (Fig. 2). Soil samples were collected at $0-3$, 3-20, 20-40, 40-60, 60-80, 80-100, 100-120, and 120-140 cm soil depth. Following the salt determination method adopted by Shao et al. (2019), samples were airdried, grounded, and screened through a 1-mm sieve, and then mixed with water. The mass ratio of soil to water was 1:5, the mixed solution was oscillated for $15 \mathrm{~min}$, and filtered to yield leachate. 


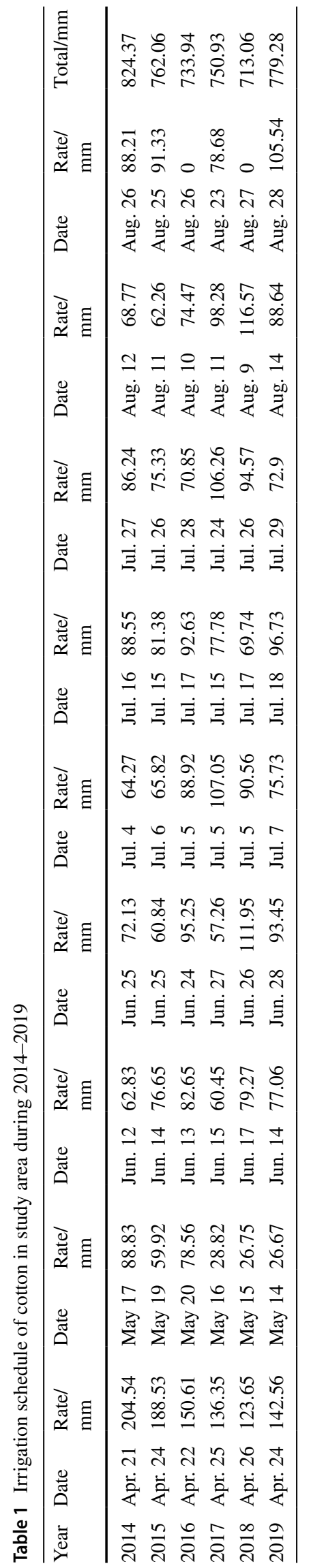

\section{Soil salinity and ions}

The electrical conductivity (EC) value of the leachate from each sample was tested using a DDS-11A digital display conductivity meter (manufactured by Shanghai Leici, China). The residual drying method was used to calibrate the conversion from $\mathrm{EC}_{1: 5}$ values into the corresponding salt mass fraction $\left(\mathrm{g} \mathrm{kg}^{-1}\right)$, and all samples were converted. The $\mathrm{Na}^{+}$concentrations in the samples were tested by a flame photometer following the method described by Sepahvand et al. (2019). The concentrations of $\mathrm{Cl}^{-}$and $\mathrm{SO}_{4}{ }^{2-}$ were measured by the $\mathrm{AgNO}_{3}$ titration method and EDTA indirect titration method. Finally, $\mathrm{Mg}^{2+}$ and $\mathrm{Ca}^{2+}$ abundances were gauged by the complexometric titration method (Aragüés et al. 2014). The results were converted into the unit of $\mathrm{g} \mathrm{kg}^{-1}$. In the first applying year of MDI, the average salt content was $24.84 \mathrm{~g} \mathrm{~kg}^{-1}$ in the $0-100 \mathrm{~cm}$ soil layer, so we categorized it as intensive saline soil combining with the saline-alkali land classification standard of Chhabra (2004). And the average of $\mathrm{Na}^{+}, \mathrm{Cl}^{-}, \mathrm{Ca}^{2+}$, $\mathrm{Mg}^{2+}$ and $\mathrm{SO}_{4}{ }^{2-}$ contents were $9.39 \mathrm{~g} \mathrm{~kg}^{-1}, 0.49 \mathrm{~g} \mathrm{~kg}^{-1}$, $1.82 \mathrm{~g} \mathrm{~kg}^{-1}, 1.22 \mathrm{~g} \mathrm{~kg}^{-1}$, and $0.78 \mathrm{~g} \mathrm{~kg}^{-1}$ in the $0-100 \mathrm{~cm}$ soil layer, respectively. The value of CSER was 0.87 , so the saline-alkaline soil in this cotton field was classified as a chloride-sulphate solonchak (Chhabra 2004).

Annual averages were calculated using the data obtained within the same soil depth and MDI years. To more intuitively reflect the evolution law of salt and ions in the cotton field across MDI 1-16a, the expression mode of storage per unit area was introduced. The salt (ions) storage per unit area $\left(\mathrm{S}, \mathrm{g} \mathrm{cm}^{-2}\right)$ in a given soil layer was calculated as

$\mathrm{S}=10 \mathrm{~h} \times \gamma \times \mathrm{c}$

where $h$ is the thickness of the soil layer $(\mathrm{cm}), \gamma$ is the bulk density of the soil $\left(\mathrm{g} \mathrm{cm}^{-3}\right)$, and $\mathrm{c}$ represents the salt (ions) content in the soil layer $\left(\mathrm{g} \mathrm{kg}^{-1}\right)$.

\section{SAR and CSER}

A proportional linear relationship existed between the sodium absorption ratio of the soil and its exchange sodium percentage (ESP), which was used as an evaluation index for alkalinity changes of soil quality in the process of improving and utilizing saline-alkali land (Robbins 1984). The standard equation for SAR ((mol $\left.\mathrm{kg}^{-1}\right)^{0.5}$ ) depended on the proportional concentrations (mol $\mathrm{kg}^{-1}$ ) of $\mathrm{Na}^{+}$to $\mathrm{Ca}^{2+}$ and $\mathrm{Mg}^{2+}$ in the soil: $\mathrm{SAR}=\mathrm{Na}^{+} /$ $\left[\left(\mathrm{Ca}^{2+}+\mathrm{Mg}^{2+}\right) / 2\right]^{1 / 2}$ (Sepahvand et al. 2019). In this study area, $\mathrm{Cl}^{-}$and $\mathrm{SO}_{4}{ }^{2-}$ were the major anions. Since $\mathrm{Cl}^{-}$easily migrates with water, while $\mathrm{SO}_{4}{ }^{2-}$ is resistant to this 
Table 2 Soil texture and bulk density at the $0-100 \mathrm{~cm}$ soil depths in the sampling location

\begin{tabular}{lllllll}
\hline Soil depth/cm & $0-5$ & $15-20$ & $35-40$ & $55-60$ & $75-80$ & $95-100$ \\
\hline Sand percentage $(2-0.02 \mathrm{~mm}) / \%$ & 74.65 & 87.67 & 89.57 & 88.32 & 87.43 & 69.57 \\
Silt percentage $(0.02-0.002 \mathrm{~mm}) / \%$ & 13.00 & 7.77 & 4.69 & 7.25 & 5.74 & 16.83 \\
Clay percentage $(<0.002 \mathrm{~mm}) / \%$ & 12.35 & 4.56 & 5.74 & 4.43 & 6.83 & 13.60 \\
Soil texture & Sandy loam & Sandy & Sandy & Sandy & Loamy sand & Sandy loam \\
Bulk density $/ \mathrm{g} \mathrm{cm}^{-3}$ & 1.28 & 1.47 & 1.49 & 1.48 & 1.49 & 1.52 \\
\hline
\end{tabular}

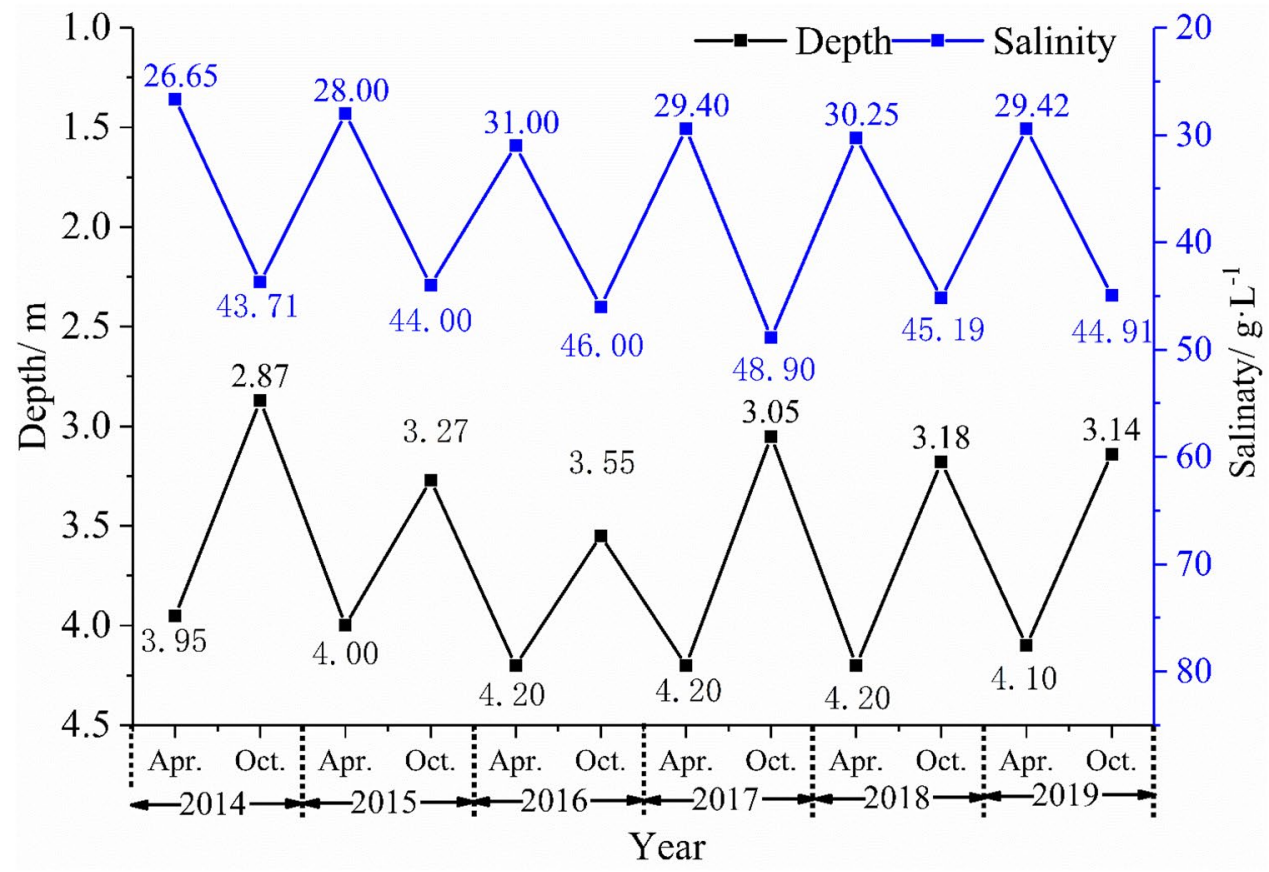

Fig. 3 Dynamic changes of groundwater level and groundwater salinity in the study area from 2014 to 2019 process, CSER can be used to evaluate anion leaching performance under MDI (equivalence ratio, the ion milligram equivalent of $1 \mathrm{~kg}$ soil is equal to the ion content in $1 \mathrm{~kg}$ of soil divided by the milligram equivalence of this ion). At the same time, saline-alkali lands can be classified by CSER valves (Chhabra 2004), which can help land managers, farmers and researchers interpret the influences of long-term MDI on saline-alkaline lands.

\section{Cotton growth}

The average survival rate and the actual yield of cotton can reflect the improvements of saline-alkali land under longterm MDI. To calculate the survival rate of cotton, three pieces of discontinuous mulching film of $3 \mathrm{~m}$ long were randomly selected, and the actual number of cotton plants in each section was counted during the boll-opening period. According to the known plant distance, it was calculated that the nominal number of cotton per section was 180 plants with six rows per film. A total of 540 cotton plants should have been planted in these 3 parts, providing a baseline value. To get an emergence rate $(\%)$, the actual number of cotton plants during the boll-opening period was divided by this nominal number. At the same time, actual cotton production ( $\mathrm{kg} \mathrm{ha}^{-1}$ ) was monitored from 2015 to 2019 (Fig. 4).

\section{Data analysis}

Origin 9.1 (OriginLab, Inc., Hampton, MA, USA) was utilized for drawing and regression analysis. The regression analysis method was conducted to analyze the relationships of the average salt content in $0-100 \mathrm{~cm}$ soil layer to MDI years, and the relationships of survival rate, yield to MDI years, salt content, SAR, CSER, respectively. The best fitting function was selected based on the coefficient of determination $\left(R^{2}\right)$.

\section{Results}

\section{Variations of soil salinity distribution}

As shown in Fig. 5a, the phenomenon of soil salt surface polymerization had existed in the cotton field of MDI under 

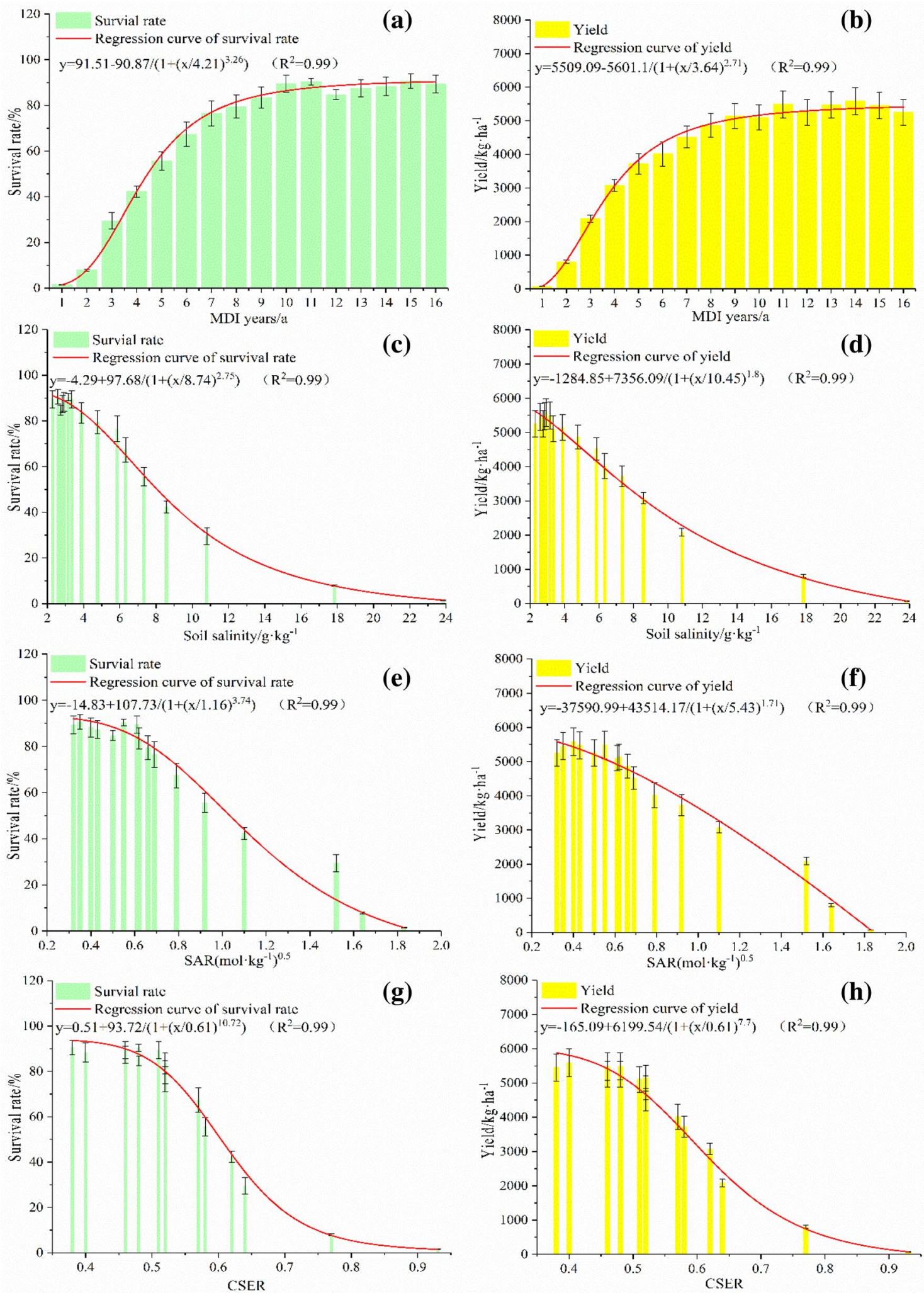

Fig. 4 a, b Cotton survival rate (numerical value \pm standard deviation) and yield (numerical value \pm standard deviation) varied with the years of MDI, $\mathbf{c}, \mathbf{d}$ with the average soil salt in the root zone, $\mathbf{e}, \mathbf{f}$ with SAR, $\mathbf{g}, \mathbf{h}$ with CSER and the logistic regression results between them 
(a)

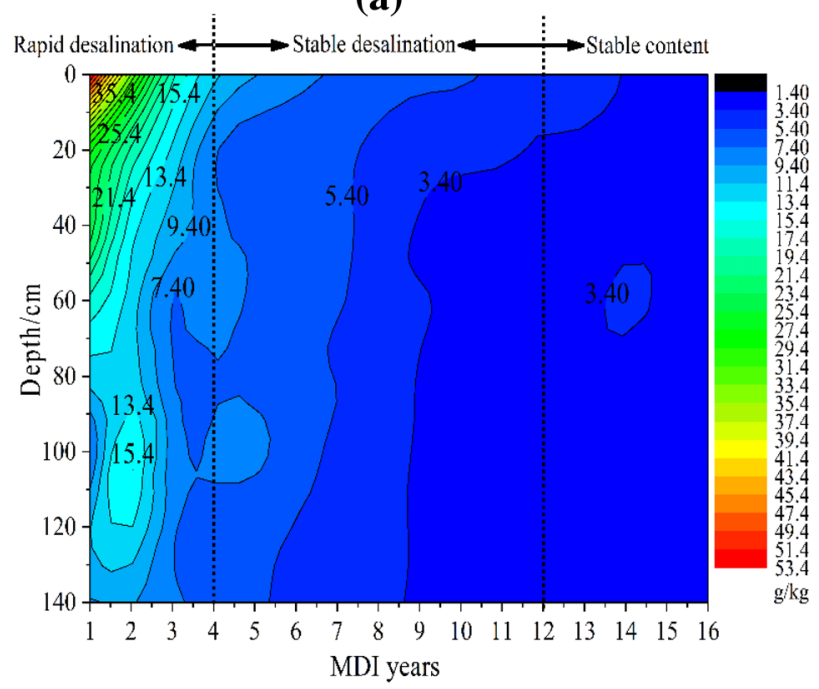

(b)

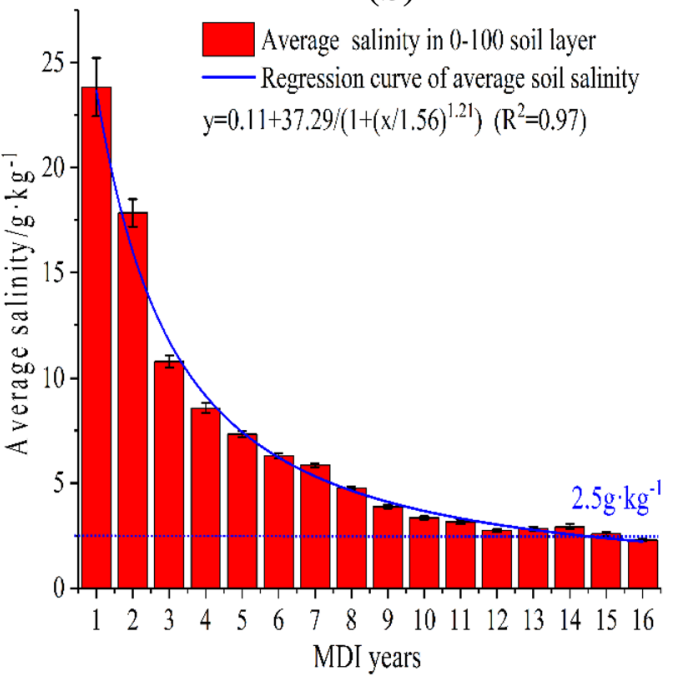

Fig. 5 a Soil salt distribution in $0-140 \mathrm{~cm}$ soil layer of cotton field during 1-16 years of MDI. b Changes of average soil salt content of cotton fields (numerical value \pm standard deviation) with different MDI years and the logistic regression model between salt content and MDI years

the dry climate. However, affected by drip irrigation, the salt content in $0-140 \mathrm{~cm}$ soil layer decreased and gradually tended to balance with the extension of MDI years. In the first year of MDI, the soil salt content was more than $54.00 \mathrm{~g} \mathrm{~kg}^{-1}$ in surface soil, but was less than $16.00 \mathrm{~g} \mathrm{~kg}^{-1}$ below $60 \mathrm{~cm}$., The salt content of $0-140 \mathrm{~cm}$ soil layer was less than $12.00 \mathrm{~g} \mathrm{~kg}^{-1}$ after 4a MDI, while was less than $6.00 \mathrm{~g} \mathrm{~kg}^{-1}$ after 8a MDI.

A logistic model was used to regress the equation of average salt content in $0-100 \mathrm{~cm}$ soil layer (root zone) of the cotton field with the years of MDI: $y=0.11+37.29$ / $\left(1+(x / 1.56)^{1.21}\right), R^{2}=0.97(x$ represents MDI year, $y$ means average salinity). The model could accurately represent the variations of soil salt content in the root zone of the cotton field with the years of MDI. The results showed that the salt content decreased and the inter-annual desalination also decreased with the extension of MDI years.

The average salt content of the root zone in the cotton field was more than $10 \mathrm{~g} \mathrm{~kg}^{-1}$ within 4 years of MDI, the degree of salinization belonged to the intensive saline soil (Chhabra 2004), and seriously inhibited crop growth at this stage (Paul and Lade 2014). During this period, the average annual desalination amount and its ratio of root zone was $8607.58 \mathrm{~g}$ and $24.93 \%$ in the cotton field, respectively, which was determined as the "rapid desalting stage". The average salt content of the cotton field was less than $10 \mathrm{~g} \mathrm{~kg}^{-1}$ and more than $3 \mathrm{~g} \mathrm{~kg}^{-1}$ during 5-11a MDI, which could be classified as moderate saline soil. The average annual desalination amount and its ratio was $1171.67 \mathrm{~g}$ and $10.92 \%$ in 5-11 a cotton field, respectively, which could be determined as the "stable desalting stage", thus inhibiting crop growth to a moderate extent. After 12 years of MDI, the average salt content of the soil was less than $2.49 \mathrm{~g} \mathrm{~kg}^{-1}$, which pertained the non-saline soil and was regarded as the "salt stable stage". During this period, crops could grow normally.

\section{Spatiotemporal migrations of ions in the soil}

The contents of $\mathrm{Na}^{+}, \mathrm{Ca}^{2+}, \mathrm{Mg}^{2+}, \mathrm{Cl}^{-}$and $\mathrm{SO}_{4}{ }^{2-}$ in cotton soil gradually decreased with the extension of MDI applying years (Fig. 6). Soil ions content rapidly decreased in the early stage of MDI, but the rate of ions reduction slowed down after a period of time of MDI. The decreasing rates of five ions were different with the extension of MDI applying years. $\mathrm{Na}^{+}$content was highest but the reduction rate of $\mathrm{Na}^{+}$

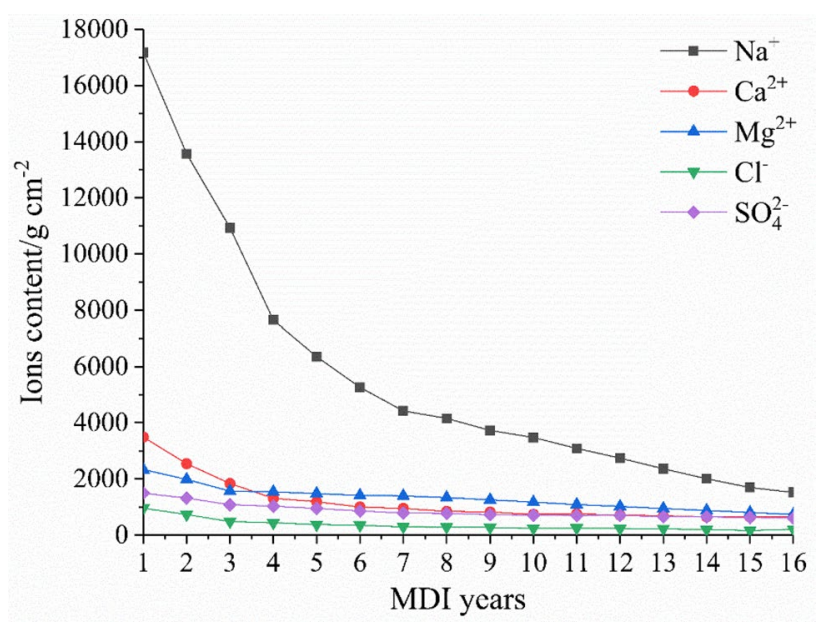

Fig. $60-140 \mathrm{~cm}$ average reserves of $\mathrm{Na}^{+}, \mathrm{Ca}^{2+}, \mathrm{Mg}^{2+}, \mathrm{Cl}^{-}$and $\mathrm{SO}_{4}{ }^{2-}$ in cotton field soil during 1-16 years of MDI 
was largest in the study. The $\mathrm{Na}^{+}$storage in $0-100 \mathrm{~cm}$ soil layers decreased from $19,858.72 \mathrm{~g} \mathrm{~cm}^{-2}$ in the first employing year of MDI to $1713.99 \mathrm{~g} \mathrm{~cm}^{-2}$ after 16 applying years of MDI, which the trend was similar to the chemical properties of $\mathrm{Ca}^{2+}$ and $\mathrm{Mg}^{2+}$ (Zhang et al. 2016). After 16 applying years of MDI, the $\mathrm{Ca}^{2+}$ and $\mathrm{Mg}^{2+}$ storages decreased by $80.96 \%$ and $68.56 \%$, respectively. Furthermore, $\mathrm{Cl}^{-}$content was lowest and $\mathrm{Cl}^{-}$storage decreased from $1107.73 \mathrm{~g} \mathrm{~cm}^{-2}$ to $215.55 \mathrm{~g} \mathrm{~cm}^{-2}$ in $1-16$ years of MDI. In the past 16 years, $\mathrm{SO}_{4}{ }^{2-}$ storage decreased by $59.65 \%$, which was a relatively stable ion in the study (Diaz Caselles et al. 2020).

\section{Variations of SAR and CSER}

As shown in Table 3, SAR in 1-16a cotton soil with MDI decreased with the extension of MDI years. Compared with $1 \mathrm{a}$ and 8th using year of MDI, SAR of 0-60, $0-100$ and $0-140 \mathrm{~cm}$ soil layers reduced by $66.5 \%, 63.9 \%$ and $61.0 \%$, respectively, In addition, SAR of three soil layers above decreased by $83.7 \%, 82.5 \%$ and $81.7 \%$, respectively, compared with 1a and 16th using year. The results showed that the relative activity of exchange reaction between $\mathrm{Na}^{+}$and the soil decreased with the extension of MDI years, and the alkalinity in the cotton field gradually decreased with the extension of MDI years. At the same time, it also reflected that the cation composition of soil salt changed.

The CSER in $0-60,0-100$ and $0-140 \mathrm{~cm}$ soil layers showed a decreasing tendency with the extension of MDI years in long-term MDI cotton field (Table 3 ). The CSER in $0-100 \mathrm{~cm}$ soil layer decreased from 0.93 in 1 a to 0.52 in $8 \mathrm{a}$ and 0.36 in 16a. In the process of salt being washed out from the soil, $\mathrm{Cl}^{-}$content, which was relatively active, decreased faster than $\mathrm{SO}_{4}{ }^{2-}$ content, and the anion composition of soil salt changed during this process. The type of saline soils in the study area had always been chloride-sulphate solonchak $\left(0.2<\mathrm{Cl}^{-} / \mathrm{SO}_{4}{ }^{2-}<1\right)($ Chhabra 2004).

\section{Cotton plant emergence and yield}

Survival rate and yield of the cotton showed three stages of "rapid growth, steady improvement and relative stability" with the extension of MDI years (Fig. 4). With the increase of average salt content, SAR and CSER in root zone soil showed the characteristics of "relatively stable, significantly inhibited, and to basically no harvest".

The survival rate of cotton rapidly increased from $1.48 \%$ in the first year to $42.04 \%$ in the fourth year of MDI, and yield also correspondingly increased from $72.43 \mathrm{~kg} \mathrm{ha}^{-1}$ to $3075.90 \mathrm{~kg} \mathrm{ha}^{-1}$. According to the annually average investment of about 4000 US dollar ha ${ }^{-1}$ and the average purchase price of lint (including government subsidies) of $1.3 \mathrm{US}$ dollar kg-1 from 2018 to 2020 , the ratio of agricultural material inputs to year-end output after the 5 th year of drip irrigation was less than 1 . At this time, the average salt content, SAR and CSER of root zone soil decreased from $23.84 \mathrm{~g} \mathrm{~kg}^{-1}$, $1.83\left(\mathrm{~mol} \mathrm{~kg}^{-1}\right)^{0.5}$ and 0.93 to $8.57 \mathrm{~g} \mathrm{~kg}^{-1}, 1.10\left(\mathrm{~mol} \mathrm{~kg}^{-1}\right)^{0.5}$ and 0.62 , respectively.

The annual survival rate and yield of cotton increased by $6.26 \%$ and $5.18 \%$ in 5 to 11 years of applying MDI, respectively. Meanwhile, average salt content, SAR and CSER in root zone soil decreased by $8.50 \%, 6.81 \%$ and $2.81 \%$, respectively. According to the regression relationship, the average salt content, SAR and CSER of root zone soil decreased to $2.49 \mathrm{~g} \mathrm{~kg}^{-1}, 0.41\left(\mathrm{~mol} \mathrm{~kg}^{-1}\right)^{0.5}$ and 0.45 after 12 years of MDI, respectively (Fig. 4). The survival rate of cotton and the yield per unit area was more than $90.39 \%$ and $5401.32 \mathrm{~kg} \mathrm{ha}^{-1}$, respectively.

Table 3 The average values of SAR and CSER at 0-60, 0-100 and 0-140 cm soil depths in cotton field soil during 1-16 years of MDI

\begin{tabular}{|c|c|c|c|c|c|c|c|c|c|c|c|c|c|c|c|c|}
\hline \multirow[t]{3}{*}{ Depth/cm } & \multicolumn{16}{|c|}{ MID years } \\
\hline & $1 \mathrm{a}$ & $2 \mathrm{a}$ & $3 a$ & $4 a$ & $5 \mathrm{a}$ & $6 a$ & $7 \mathrm{a}$ & $8 \mathrm{a}$ & $9 \mathrm{a}$ & $10 \mathrm{a}$ & $11 \mathrm{a}$ & $12 \mathrm{a}$ & $13 \mathrm{a}$ & $14 \mathrm{a}$ & $15 \mathrm{a}$ & $16 \mathrm{a}$ \\
\hline & \multicolumn{16}{|c|}{ SAR $\left(\mathrm{mol} \mathrm{kg}^{-1}\right)^{0.5}$} \\
\hline $0-60$ & 2.03 & 1.88 & 1.75 & 1.2 & 1.02 & 0.86 & 0.71 & 0.68 & 0.61 & 0.6 & 0.51 & 0.49 & 0.42 & 0.37 & 0.34 & 0.33 \\
\hline $0-100$ & 1.83 & 1.64 & 1.52 & 1.1 & 0.92 & 0.79 & 0.69 & 0.66 & 0.62 & 0.61 & 0.55 & 0.5 & 0.43 & 0.4 & 0.35 & 0.32 \\
\hline \multirow[t]{2}{*}{$0-140$} & 1.64 & 1.47 & 1.36 & 1.02 & 0.89 & 0.77 & 0.65 & 0.64 & 0.59 & 0.57 & 0.53 & 0.48 & 0.43 & 0.38 & 0.33 & 0.30 \\
\hline & CSER & & & & & & & & & & & & & & & \\
\hline $0-60$ & 0.9 & 0.79 & 0.7 & 0.7 & 0.6 & 0.55 & 0.52 & 0.55 & 0.58 & 0.53 & 0.53 & 0.54 & 0.48 & 0.45 & 0.45 & 0.47 \\
\hline $0-100$ & 0.93 & 0.77 & 0.64 & 0.62 & 0.58 & 0.57 & 0.52 & 0.52 & 0.52 & 0.51 & 0.48 & 0.48 & 0.46 & 0.4 & 0.38 & 0.36 \\
\hline $0-140$ & 0.87 & 0.76 & 0.61 & 0.59 & 0.55 & 0.56 & 0.52 & 0.51 & 0.52 & 0.46 & 0.5 & 0.45 & 0.47 & 0.42 & 0.36 & 0.37 \\
\hline
\end{tabular}




\section{Discussion}

\section{Changes and causes of soil salinity in cotton field with a continuous extension of MDI}

After drip irrigation, the soil water content in the direction parallel to the drip irrigation tape was higher than that in the vertical direction (Chen et al. 2014). The lowest soil salt was found under the drip irrigation tape, which was accumulated on wetting front and exposed soil surface (Li et al. 2014; Zhang et al. 2014). However, the result was not in accordance with previous study that the change trends of $\mathrm{Cl}^{-}$, SAR and electrical conductivity were not difference after irrigation (Aragüés et al. 2014). The author confirmed that the soil salt, ions, SAR and CSER of the long-term MDI cotton field all decreased with the extension of MDI years due to the drip irrigation effect on salt displacement and the changed soil salt composition (Figs. 5 and 6, Table 3).

Li et al. (2012) and Tan et al. (2008) found that the soil salt content decreased after 1-2a of MDI in spring corn fields and former wasteland. The result was in agreement with the observations in this study. However, Li et al. (2012) and Tan et al. (2008) did not provide a deep analysis for the characteristics of the salt decline trend and salt composition. Some observations indicated that the application of MDI would lead to the accumulation of soil salt. Wang et al. (2013) and Rohit Katuri et al. (2019) believed that the salt accumulated in the root zone by means of the deficit drip irrigation. Additionally, Wang et al. (2013) pointed out that flood irrigation after harvest would not lead to soil salinization. Therefore, the larger irrigation quota was a major factor in the decrease of salt content in the study area.

Al-Muaini et al. (2019) and Chen et al. (2009) found that irrigation using brackish water resulted in salt accumulation after the end of the growing period. Mmolawa (2000a; b) had illustrated that drip irrigation with poor quality water could also lead to salt accumulation in the root zone. But Al-Muaini et al. (2019) pointed out that the increase of irrigation amount could inhibit the return of salt. Wan et al. (2007) demonstrated that the reasonable brackish water irrigation strategy would not cause salt accumulation with MDI. Therefore, reasonable irrigation water quality was also a factor leading to the decrease of soil salt in the study area.

\section{Response characteristics of groundwater level and salinity in the study area}

The leaching of soil salt to the deep layer by irrigation water (3.1 in this paper) may influence the shallow groundwater level and salinity in the region. The changes in shallow groundwater level and salinity in this study area from April and October 2014 to 2019 are shown in Fig. 3. In this study, the groundwater level significantly increased from April to October but decreased from October to April between 2 years. The groundwater salinity was against to the change of groundwater level. From 2014 to 2019, the regional groundwater level was between $3.05-4.20 \mathrm{~m}$, and the groundwater salinity was between $26.65-48.90 \mathrm{~g} \mathrm{~L}^{-1}$. There was no significant change between 2 years.

Irrigation practices significantly affected groundwater (Rotiroti et al. 2019; Tian et al. 2019). As a result, the shallow groundwater level significantly increased from April to October in this study. During irrigation season, plain reservoirs keep storing water, the channels transmitted and distributed irrigation water. The infiltrated freshwater served to dilute the groundwater (Jia et al. 2020), which resulted in gradual decrease of groundwater salinity. In non-irrigation season, groundwater level gradually decreased, and the salinization of groundwater occurred. The same results in coastal areas was presented by Takase and Fujihara (2019). Therefore, the dynamic change of shallow groundwater was also a necessary condition for the increase of cotton field yield under long-term MDI in this study area.

\section{Relationship between cotton growth, soil salt environment and suggestions for irrigation regulation}

For many crops, high soil salt content resulted in the decrease of 50-80\% in average farmland yields (Shrivastava and Kumar 2015). Cotton is a moderately salt-tolerant flora, Ashraf (2010) concluded that the salt threshold of cotton was $7.7 \mathrm{dsm}^{-1}$. Chen et al. (2009) showed that when the soil salt content was up to $12.5 \mathrm{dsm}^{-1}$, the dry mass of cotton seeds was reduced by $52 \%$ compared with $2.4 \mathrm{dsm}^{-1}$ in a greenhouse experiment. In addition, they showed that appropriate nitrogen application could increase yield under low and medium soil salinization conditions. Zhang et al. (2017) determined the salt tolerance threshold of cotton by designing a barrel planting experiments device which could control the groundwater level. Therefore, the cotton salt tolerance threshold was affected by multiple factors such as test conditions and climate. We found that cotton growth was severely inhibited when the average soil salt, SAR, and CSER in the root zone of the cotton field were greater than $8.57 \mathrm{~g} \mathrm{~kg}^{-1}, 1.10\left(\mathrm{~mol} \mathrm{~kg}^{-1}\right)^{0.5}$ and 0.62 , respectively, under MDI in the oasis area.

Previous observations indicated tha the economic benefit and water use efficiency of the cotton yield reached more than $90 \%$ in the suitable irrigation quota with a range of $362.3-462.5 \mathrm{~mm}$ for the cotton growth period under MDI in Xinjiang (Gao et al. 2010; Wang et al. 2018a; Zhou et al. 
2012).. Liu et al. (2012) suggested that a $150 \mathrm{~mm}$ salt washing quota should be used to prevent secondary salinization in the non-growth period of cotton in arid oasis areas. Wang et al. $(2011,2018 b)$ considered that the suitable irrigation quota was between $617.0-636.4 \mathrm{~mm}$ in the cotton field with saline-alkali under MDI in Xinjiang. After 3 years of research, soil from the cotton field in the study area has gradually changed from intensive saline soil to moderate saline soil, and this quota was similar to the sum of the irrigation quota for cotton growth period and non-growth period in the existed results. Therefore, the irrigation quota of $760.61 \mathrm{~mm}$ caused a waste of water resources between $124.21-143.61 \mathrm{~mm}$ in cotton field with MDI of arid oasis area.

Xiayedi irrigation area of Manas River Basin is a typical representative of arid oasis area, especially in northern Xinjiang. Water resources are scarce and soil salinization is serious in Xinjiang. Farmers should further enhance their awareness of water-saving in practice and implement irrigation quota management. In addition, scientific research achievements also need to be popularized. Exploring the fine coupling regulation of irrigation quota and irrigation water quality at the farmland scale and studying the watersalt balance from farmland to irrigation area are of great significance for improving the efficiency of agricultural water use in irrigation areas and ensuring sustainable development of oasis agriculture.

\section{Conclusions}

In this study, we investigated the spatial-temporal variation of soil salt and ions in cotton field with 1-16a MDI by continuous location monitoring. In addition, we examined the cotton growth situation and its main influencing factors in the study area. We found that the cotton field in salinealkali land experienced a change from strong saline soil to moderate saline soil and finally formed non-saline soil in the process of long-term MDI. Soil salt contents decreased in cotton field with years of MDI, which could be fitted by logistic model and thus divided into three deceasing stages, i.e., rapid desalination, slow desalination and relatively stable desalination. The main ions, SAR and CSER in cotton soil decreased and soil salt composition changed with the extension of MDI years, which did not result in change of the soil type of chloride-sulphate solonchak. The survival rate and yield of cotton experienced rapid increase, then slow increase and finally relative constant with the extension of MDI years due to the improvement of the salt environment in the root zone. Cotton growth was seriously inhibited as the average salt content of root zone soil was more than $8.57 \mathrm{gkg}^{-1}$. However, when the average salt content was less than $2.49 \mathrm{gkg}^{-1}$, cotton growth would not be affected by salt stress, and thus the survival rate and yield per unit area of cotton also was more than $90.39 \%$ and $5401.32 \mathrm{kgha}^{-1}$, respectively. Our results provide the reliable theory foundation and practical technical support with the sustainable application of MDI technology and the development of cotton industry.

Acknowledgements We are grateful for the financial support from the National Natural Science Foundation of China (51869028, 51869027) and the Innovation Team in Key Areas of Corps (2019CB004). The authors would like to thank all members at Key Laboratory of Modern Water-Saving Irrigation of Xinjiang Production \& Construction Group for monitoring and providing places and facilities in the experiments.

\section{Declarations}

Conflict of interest On behalf of all authors, the corresponding author states that there is no conflict of interest.

Open Access This article is licensed under a Creative Commons Attribution 4.0 International License, which permits use, sharing, adaptation, distribution and reproduction in any medium or format, as long as you give appropriate credit to the original author(s) and the source, provide a link to the Creative Commons licence, and indicate if changes were made. The images or other third party material in this article are included in the article's Creative Commons licence, unless indicated otherwise in a credit line to the material. If material is not included in the article's Creative Commons licence and your intended use is not permitted by statutory regulation or exceeds the permitted use, you will need to obtain permission directly from the copyright holder. To view a copy of this licence, visit http://creativecommons.org/licenses/by/4.0/.

\section{References}

Al-Muaini A, Green S, Dakheel A et al (2019) Irrigation management with saline groundwater of a date palm cultivar in the hyper-arid United Arab Emirates. Agric Water Manag 211:123-131

Aragüés R, Medina ET, Clavería I (2014) Effectiveness of inorganic and organic mulching for soil salinity and sodicity control in a grapevine orchard drip-irrigated with moderately saline waters. Span J Agric Res 12(2):501-508

Ashraf M (2010) Salt tolerance of cotton: some new advances. Crit Rev Plant Sci 21(1):1-30

Casas C, Bella CE, Lattanzi FA et al (2019) A highly productive grass improves chemical and biological properties but does not aggregate stability in saline-sodic lowlands in Argentina. Arch Agron Soil Sci 66(11):1532-1545

Chen M, Kang YH, Wan SQ et al (2009) Drip irrigation with saline water for oleic sunflower (Helianthus annuиs L.). Agric Water Manag 96:1766-1772

Chen LJ, Feng Q, Li FR et al (2014) A bidirectional model for simulating soil water flow and salt transport under mulched drip irrigation with saline water. Agric Water Manag 146:24-33

Chhabra R (2004) Classification of salt-affected soils. Arid Land Res Manag 19(1):61-79

Diaz CL, Hot J, Roosz C et al (2020) Stabilization of soils containing sulfates by using alternative hydraulic binders. Appl Geochem 113:104494

Fang SB, Tu WR, Mu L et al (2019) Saline alkali water desalination project in southern Xinjiang of China: a review of desalination 
planning, desalination schemes and economic analysis. Renew Sustain Energy Rev 113:109268

Gao LT, Fu Q, Ni GH et al (2010) Experimental study on soil water-salt movement and irrigation scheduling for cotton under mulched drip irrigation condition. J Water Conserv 41(12):1483-1490

Guan ZL, Jia ZF, Zhao ZQ et al (2019) Dynamics and distribution of soil salinity under long-term mulched drip irrigation in an arid Area of northwestern China. Water 11:1225

Jia H, Qian H, Zheng L et al (2020) Alterations to groundwater chemistry due to modern water transfer for irrigation over decades. Sci Total Environ 717:137170

Li M, Liu HG, Zheng XR (2012) Spatiotemporal variation for soil salinity of field land under long-term mulched drip irrigation. Trans Chin Soc Agric Eng 28(22):82-87 ((in Chinese with English abstract))

Li XW, Jin MG, Huang JO et al (2014) The soil-water flow system beneath a cotton field in arid north-west China, serviced by mulched drip irrigation using brackish water. Hydrogeol J 23(1):35-46

Li M, Du YJ, Zhang FC et al (2019) Simulation of cotton growth and soil water content under film-mulched drip irrigation using modified CSM-CROPGRO-cotton model. Agric Water Manag 218:124-138

Liu MX, Yang JS, Li XM et al (2012) Distribution and dynamics of soil water and salt under different drip irrigation regimes in northwest China. Irrig Sci 31(4):675-688

Lothrop N, Bright KR, Sexton J et al (2018) Optimal strategies for monitoring irrigation water quality. Agric Water Manag 199:86-92

Mmolawa K O, Dani. Root zone solute dynamics under drip irrigation: A review. Plant and Soil, 2000a, 222: 163-190.

Mmolawa K, Dani O (2000b) Water and solute dynamics under a dripirrigated crop: experiments and analytical model. Am Soc Agric Eng 46(6): 1597-1608

Morais PADO, Souza DMD, Carvalho MTDM et al (2019) Predicting soil texture using image analysis. Microchem J 146:455-463

Muhammad T, Zhou B, Liu ZY et al (2021) Effects of phosphorus-fertigation on emitter clogging in drip irrigation system with saline water. Agric Water Manag 243:106392

Ning SR (2015) Numerical simulation on soil salt accumulation in root zone of cotton field under long-term film mulched drip irrigation. Doctor, China Agricultural University (in Chinese with English abstract).

Paul D, Lade H (2014) Plant-growth-promoting rhizobacteria to improve crop growth in saline soils: a review. Agron Sustain Dev 34(4):737-752

Robbins CW (1984) Sodium adsorption ratio-exchangeable sodium percentage relationships in a high potassium saline-sodic soil. Irrig Sci 5(5): 173-179

Rohit KJ, Trifonov P, Arye G (2019) Spatial distribution of salinity and sodicity in arid climate following long term brackish water drip irrigated olive orchard. Water 11(2556):1-14

Rotiroti M, Bonomi T, Sacchi E et al (2019) The effects of irrigation on groundwater quality and quantity in a human-modified hydrosystem: the Oglio River basin, Po Plain, northern Italy. Sci Total Environ 672:342-356

Sahin U, Eroğlu S, Sahin F (2011) Microbial application with gypsum increases the saturated hydraulic conductivity of saline-sodic soils. Appl Soil Ecol 48(2):247-250

Sepahvand A, Singh B, Sihag P et al (2019) Assessment of the various soft computing techniques to predict sodium absorption ratio (SAR). J Hydraul Eng 11:1-12
Shao TY, Gu XY, Zhu TS et al (2019) Industrial crop Jerusalem artichoke restored coastal saline soil quality by reducing salt and increasing diversity of bacterial community. Appl Soil Ecol 138:195-206

Shrivastava P, Kumar R (2015) Soil salinity: a serious environmental issue and plant growth promoting bacteria as one of the tools for its alleviation, Saudi. J Biol Sci 22(2):123-131

Takase K, Fujihara Y (2019) Evaluation of the effects of irrigation water on groundwater budget by a hydrologic model. Paddy Water Environ 17(3):439-446

Tan JL, Kang YH, Jiao YP et al (2008) Characteristics of soil salinity and salt ions distribution in salt-affected field under mulch-drip irrigation in different planting years. Trans Chin Soc Agric Eng 24(6):59-63 ((in Chinese with English abstract))

Tian YL, Zhang GH, Zhang XY et al (2019) Environmental study on the quantitative relationship between precipitation, aeration zone water and groundwater in taihang piedmont plain agricultural areas. Ekoloji 28(207):4663-4669

Wan SQ, Kang YH, Wang D et al (2007) Effect of drip irrigation with saline water on tomato (Lycopersicon esculentum Mill) yield and water use in semi-humid area. Agric Water Manag 90(1-2):63-74

Wang RS, Kang YH, Wan SQ et al (2011) Salt distribution and the growth of cotton under different drip irrigation regimes in a saline area. Agric Water Manag 100:58-69

Wang ZM, Jin MG, Šimůnek J et al (2013) Evaluation of mulched drip irrigation for cotton in arid Northwest China. Irrig Sci 32(1): $15-27$

Wang HD, Wu LF, Cheng MH et al (2018a) Coupling effects of water and fertilizer on yield, water and fertilizer use efficiency of dripfertigated cotton in northern Xinjiang. China Field Crops Res 219:169-179

Wang RS, Wan SQ, Sun JX et al (2018b) Soil salinity, sodicity and cotton yield parameters under different drip irrigation regimes during saline wasteland reclamation. Agric Water Manag 209:20-31

Yang PN, Dong XG, Liu L et al (2011) Soil salt movement and regulation of drip irrigation under plastic film in arid area. Trans Chin Soc Agric Eng 27(12):90-95 ((in Chinese with English abstract))

Zhang Z, Hu H, Tian FC et al (2014) Soil salt distribution under mulched drip irrigation in an arid area of northwestern China. J Arid Environ 104:23-33

Zhang D, Liu HB, Hu WL et al (2016) The status and distribution characteristics of residual mulching film in Xinjiang. China J Integ Agric 15(11):2639-2646

Zhang H, Li DS, Zhou Z et al (2017) Soil water and salt affect cotton (Gossypium hirsutum L.) photosynthesis, yield and fiber quality in coastal saline soil. Agric Water Manag 187:112-121

Zheng W, Xue DM, Li XZ et al (2017) The responses and adaptations of microbial communities to salinity in farmland soils: a molecular ecological network analysis. Appl Soil Ecol 120:239-246

Zhou SQ, Wang J, Liu JX et al (2012) Evapotranspiration of a dripirrigated, film-mulched cotton field in northern Xinjiang. China Hydrol Process 26(8):1169-1178

Publisher's Note Springer Nature remains neutral with regard to jurisdictional claims in published maps and institutional affiliations. 